\title{
Tourist Activity and Low Cost Airlines in the Mediterranean Spanish Arch
}

\author{
Roberto Díez Pisonero (Corresponding author) \\ Department of Regional Analysis in Geography \\ Complutense University of Madrid, Spain
}

Tel: 34-91-394-60-56Ｅ-mail: rdpisonero@ghis.ucm.es

\author{
Received: September 22, 2014 Accepted: October 31, 2014 Published: January 5, 2015 \\ doi:10.5296/ijssr.v3i1.6866 URL: http://dx.doi.org/10.5296/ijssr.v3i1.6866
}

\begin{abstract}
The emergence of the low cost airlines (LCA) in Spain has meant a revolution in air transportation since it has allowed fare reductions, and a growing evolution in the number of passengers and companies in many airports of the country. Nevertheless, this revolution isn't limited exclusively to air transport; there's a new urban order, more decentralized and articulated, as a consequence of the renaissance of obsolete airports tied to these airlines located in intermediate cities.

One of the best regions in which this incipient situation is most clearly seen is the Mediterranean Spanish arch, where several cities have scaled to new positions in the new urban Spanish hierarchy from the birth of these airlines. This paper will attempt to quantify the tourist growth of this region from the emergence of these LCAs until the onset of the current economic and political crisis through comparative study of different socioeconomic variables.
\end{abstract}

Keywords: low cost airlines, tourist activity, secondary airports, urban hierarchy, Mediterranean region

\section{The Spanish Mediterranean Arch}

Historically, the Mediterranean Sea has been a space that has generated not only commercial exchanges, but it has constructed a cultural space and landscape where there are today a lot of countries of Europe, Maghreb and Middle East; architectural styles, languages, customs, identities and definitively, own idiosyncrasies have coexisted and have spread lengthways of the maritime perimeter of the Mediterranean Sea. 


\section{Macrothink}

The genesis of the concept "Mediterranean arch" has its origin in the Conference of Peripheral Maritime Regions, born in 1973 as counterweight to the prevalence of the big axes of growth of the Central Europe, but it is not until the presentation of the document "Europe 2000 +. Cooperation for the coordination of the European space" of the European Commission when the concept of Mediterranean Arch is defined as an unavoidable space of its history where the modern bases of cooperation, infrastructures and especially, commercial exchanges, turn it into a constant perimeter of exchanges and institutional mutual understanding.

Little by little, the arch, even without having the clear limits, has been evolving from a confused idea to a spatial reality that is consolidated and that every time has more penetrated into the institutions of local and regional character, since they considerate the possibility of promoting the competitive advantages of a territory across the interregional collaboration.

In Spain, if we draw the regions from South to North, we would have to cove the area from the Strait of Gibraltar to Pyrenees border France, including Balearic Islands. Its principal characteristic lies in an economy consolidated and based in the exploitation of the tourist resources, where the special climatic characteristics, with near 2.500 hours of sun a year, provide to this environment a few privileged conditions for the development of this economic activity, which has its principal clients in the national and European tourism.

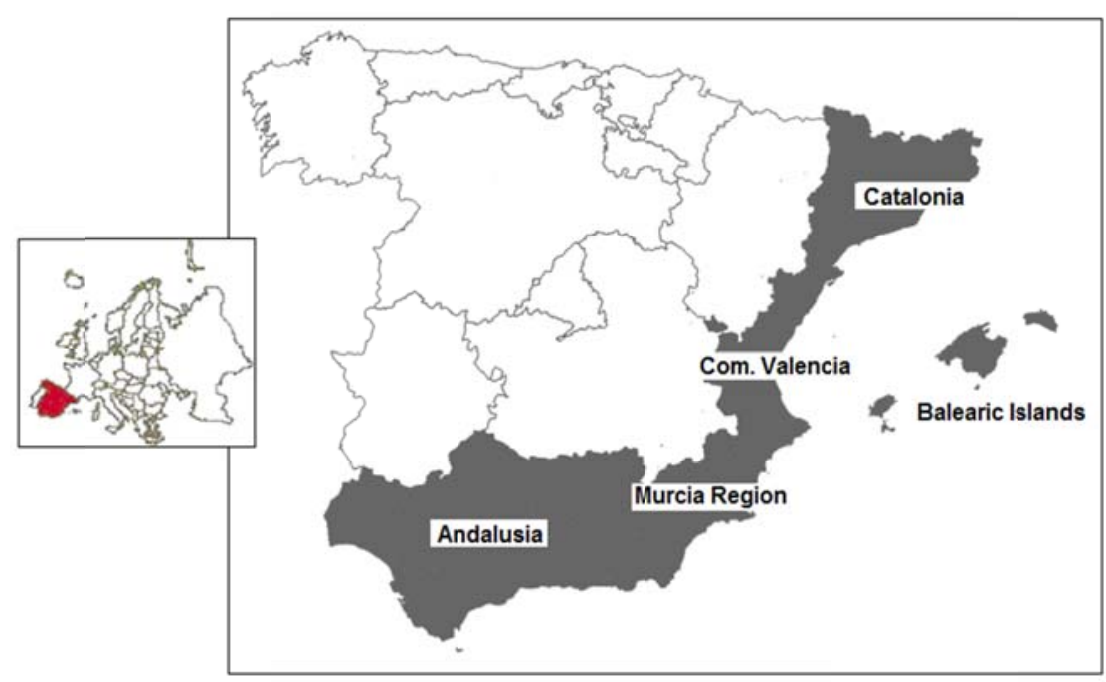

Figure 1. The Spanish Mediterranean Arch Source: Own elaboration

\section{Globalization, Air Transportation and Low-Cost Phenomenon}

Today's globalized world is an interconnected reality. If Internet and IT (Information Technology) have had and continue to have a decisive influence on globalization trends (Pedreño, 2007), we cannot forget the important contributions that modern systems of transport, especially the aviation sector, are playing in this contemporary globalization. 
In this context, air transport, though it has not abolished the distances between countries, has drastically reduced the time required to traverse them, creating not only the perception, but also the reality of a world that is shrunk: both in terms of physical accessibility and in the more complex plane of cultural hybridization.

But just when we believed that everything had already been written on this sector, there appeared in the old continent the airlines called low cost at the end of last century, fruits of the process of liberalization experienced by the air sector following the American directive of Desregulation Act, 1978.

Since then, these airlines have not stopped extending their flows, consolidating the air market and revolutionizing traditional concepts seated in the literature and in the practice of air transport, fomenting competition in the whole chain of the aviation industry and contributing widely to a democratization of air transport.

The strong growth experienced during recent years, materialized in the increasing number of passengers, companies, routes and frequencies, allows us to speak about a phenomenon of great importance and repercussion, viewed by many authors as a "revolution" of the air panorama”.

Consequently, the Spanish airline structure has been modified and convulsed by these companies that are devastating regional airlines, diminishing charter, and motivating the restructuring and increased competitiveness of traditional companies.

Aiming to offer some tariffs at very economic prices (low cost), these airlines operate with a business model based on optimizing efficiency and maximizing profitability (marketing across Internet, nonexistence of scales and interconnecting flights, homogenization of fleets, high density of seats, on board services restricted and requiring payment, strict restrictions of baggage weight, among others.). Nevertheless, in spite of the fact that these strategies have come to define the low cost model, nowadays it is appropriate to speak of a multi-faceted low cost model (Ivars Baidal, 2006), where certain common elements coexist with clearly changeable others, since there are many airlines of this type that seek to differentiate themselves by breaking with certain features of the traditional model.

\section{The Relevancy of Regional Airports in the Spanish Mediterranean Region}

Air traffic, as with maritime traffic and unlike ground traffic, does not require a fixed network of infrastructures to regulate traffic, but relies on airports, as units for stopover and exchange (Serrano Martínez, 2002).

The conception of these places has evolved over the last few years: from simple infrastructures to facilitate aeronautical operations (landing, takeoff), they have been transformed into authentic airport cities, with all kinds of services centers; with functions not only tied to air transport, but also complementary and auxiliary to it. That is, we have passed from the airport as a point isolated in space towards the relational airport, linked not only with other transportation infrastructures but also with other airport facilities. 


\section{Macrothink}

In this global world that we live in, airports play an essential function - to materialize the necessary interconnectivity for contemporary globalization: to connect territorially with the rest of the world in a direct way. Hence, such an infrastructure endows the regions where they are located with prestige, reputation, centrality, functionality and internationalization.

In this context, low cost airlines, with their point-to-point business model (opposite to that of contribution and dispersion associated with the principal airport hubs), have produced the renaissance and dynamization of a few infrastructures that, until recently, were classed as obsolete, archaic, inefficient and underutilised. A reality totally different from the current one since, thanks to the low cost phenomenon these regional airports have led the major growth seen in recent years.

Different conceptions exist to define these airport installations but, using only two parameters, we can identify them as those that, before the arrival of the LCA, were not generating more than one million passengers and that are distant from major cities (the distance limit differs among authors, ranging from 20 to $180 \mathrm{~km}$ ).

The principal Spanish airports of this modality are located in the Mediterranean Spanish region, supported by the tourist importance in this area. Air traffic in the smallest airports such a Girona, Reus or Murcia is dominated almost totally by low cost airlines; even over 95\% in some of them. Nevertheless, the smallest airports not only receive the flights of the low cost airlines, but in some of the largest Spanish airports (Barcelona, Valencia, Malaga or Alicante) also operate low fares airlines.

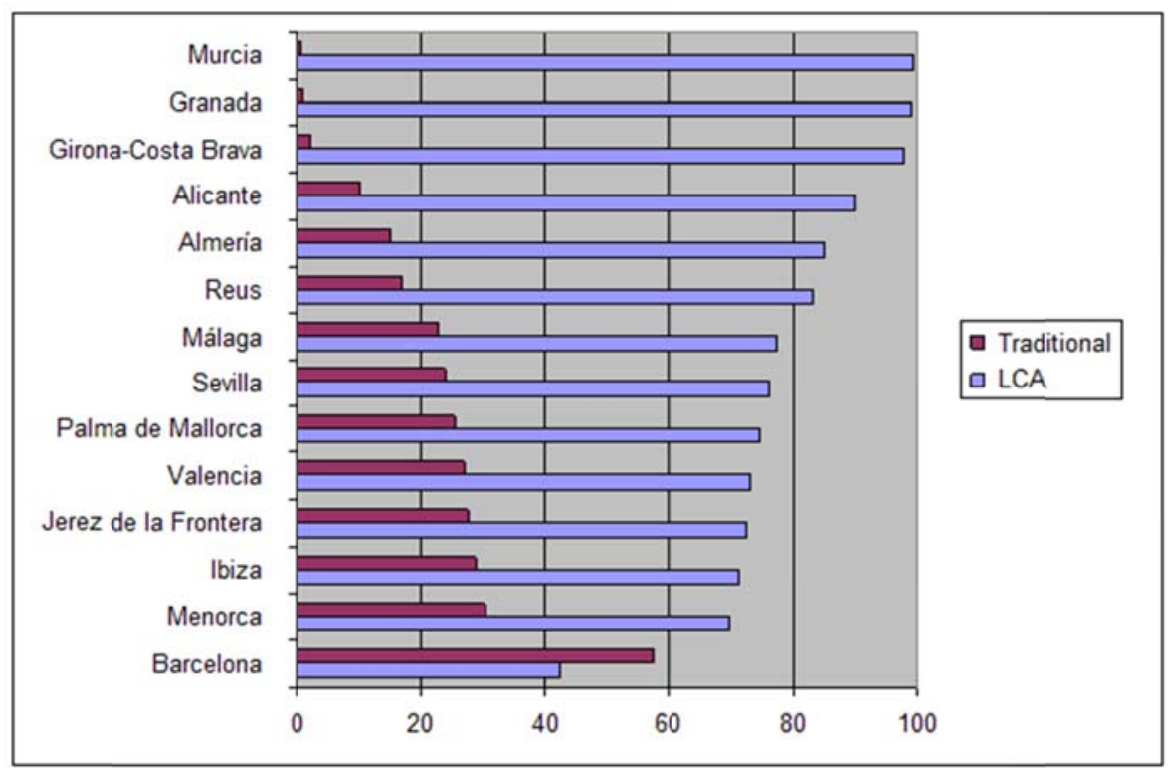

Figure 2. Proportion of Low Cost Airlines and Traditional Airlines in the airports of the Mediterranean Spanish Arch (2010)

Source: Own elaboration as from dates AENA (Airports and Air Navigation of Spain) 
The tourist importance of Gerona, Murcia and Jerez played a crucial role in the attraction of the vacation packages and international charter traffic (Britannia, Airtours and JMC mainly). But at present, most of the air traffic is regular (national and international) thanks to the LCAs since reduce the length of the principal British and German cities to the Spanish Costa Brava and Cálida, respectively.

The Girona airport, alternative of Barcelona-El Prat airport, constitutes the most representative example in Spain of the low cost in a secondary airport. The airline Ryanair chose this city as principal hub in the southern Europe, which explains the exponential growth of the number of passengers that this infrastructure has developed so far. However, the current economical recession has stopped this trend.

The Ryanair effect also has been obvious in other coastal airports such a Murcia-San Javier or Jerez. The first one has experienced a strong and constant growth during the last years (150,000 pax in 2000; 2,000,000 in 2009). Two are the principal limitations that we might find in Murcia-San Javier airport: its subjection to Alicante (internationally it is known as Alicante - South) and its exclusive military use during the mornings which restricts glaringly its operability. To minimize this restriction, Corvera Murcia airport is in construction which will compete with Murcia-San Javier.

Likewise, the Jerez airport has also evolved glaringly the number of passengers for last decade. Nevertheless, its limitation resides in the nearness of other Andalusian airports, such a Seville or Malaga, which they suppose a strong competition.

Nevertheless, it is necessary to emphasize that, in spite of the great growth experienced on three analyzed cases, there is a great dependence of an airline, Ryanair. The market share in Gerona, Murcia and Jerez is over $80 \%$. This may be a disadvantage for these infrastructures because they are obliged to the airline claims, since this airline may change its location and it is not a big problem for it.

All these airports have experienced a growth without precedents for the last years, only stopped by the economic - financial world crisis initiated in 2007-2008. The destinations of the companies of cheap flights do not stop multiplying and air traffic continues growing on the Mediterranean Spanish arch. 
Table 1. Evolution of passengers and air links in airport of the Mediterranean Spanish Arch (1970-2010)

\begin{tabular}{lllllll}
\hline & \multicolumn{2}{l}{$\mathrm{N}^{\mathrm{O}} \mathrm{Pax}$} & & \multicolumn{3}{c}{$\mathrm{N}^{\mathrm{o}}$ air links } \\
\cline { 2 - 7 } & 1970 & 2010 & Variation (\%) & 1970 & 2010 & $\begin{array}{l}\text { Variation } \\
(\%)\end{array}$ \\
\hline Gerona & 696.804 & 5.286 .970 & 758,7 & 3 & 52 & 1733,3 \\
Barcelona & 2.828 .713 & 27.421 .682 & 969,4 & 26 & 144 & 553,8 \\
Reus & 31.137 & 1.706 .615 & 5481,0 & 0 & 13 & -- \\
Valencia & 458.987 & 4.748 .997 & 1034,7 & 9 & 53 & 588,9 \\
Alicante & 804.045 & 9.139 .479 & 1136,7 & 6 & 76 & 1266,7 \\
Murcia & 37.896 & 1.630 .684 & 4303,1 & 3 & 24 & 800,0 \\
Almería & 55.580 & 791.837 & 1424,7 & 5 & 13 & 260,0 \\
Málaga & 1.678 .393 & 11.622 .429 & 692,5 & 12 & 82 & 683,3 \\
Granada & 12 & 1.187 .813 & 9898441,7 & 2 & 9 & 450,0 \\
Jerez & 566 & 1.079 .616 & 190744,9 & & 13 & -- \\
Sevilla & 422.413 & 4.051 .392 & 959,1 & 9 & 30 & 333,3 \\
Palma de Mallorca & 4.666 .502 & 21.203 .041 & 454,4 & 13 & 81 & 623,1 \\
Ibiza & 878.387 & 4.572 .819 & 520,6 & 5 & 23 & 460,0 \\
Menorca & 238.992 & 2.433 .666 & 1018,3 & 2 & 11 & 550,0 \\
\hline
\end{tabular}

Source: Own elaboration as from dates AENA and ABC Guides.

These infrastructures exceed the mere function of providing transportation and, consequently, not only reverberate in the air sector, but also help to intensify the territorial effect of the airports. That is, the social and economic value of these terminals makes a bigger joint possible and territorial vertebration, positioning their regional environments in relation to other areas and promoting the growth development of new socioeconomic activities (Henneberg, J.M; Tapiador, F.J., 2007).

Because of that, we must remove ourselves from those topics that distort the reality. According to Josep Francesc Valls, professor of ESADE (Spanish center of Business and Touristic topics) and an expert in the matter, "It is a deceit to believe that the LCA only bring cheap tourism: they bring tourists who take advantage of the possibility of spending less in the trip. From there, the dynamics are clear, since the big growth of pasisengers have given rise to more employment, more hotels and hotel management, more tourism, more real-estate construction, changes in the urban hierarchy, more commercial space and major infrastructure investments”.

These words demonstrate the important consequences that these airlines represent for regional development. Even more important than they appear at first sight. Hence, the considerations that the Assembly of the European Regions exposed in the year 2004:

"The cooperation between low cost carriers and regions is successful by contributing enormously to European integration and regional development. 


\section{Macrothink}

(...) Regions are experiencing increased economic growth in sectors such as tourism and witnessing the development of small and medium-sized enterprises in a Wide range of commercial sectors".

\section{Renaissance of Intermediate Cities in the Mediterranean Spanish Arch}

The Mediterranean Spanish airports play a role very outstanding in the entire country, since over $70 \%$ of 200 million passengers who were registered in 2009, used the Mediterranean Spanish region. The tourist importance and the development of the airlines low cost are the two main factors that explain this situation.

In Spain, a few number of airports can be considered of general interest (for their volume of traffic, location, activity and strategic position). The rest do not play a primary in the national and international sphere; hence, the name of second- and third-level infrastructures. However, though they do not register a significant quantitative impact, these airports play a very important role on the regional scale, creating a denser and more complex airport network. contributing to do more complex and to guarantee a denser airport and thick network.

The growth of a network of interregional air linkages is increasing the mobility of citizens and, consequently, a major traffic in the secondary airports. This means a socioeconomic dynamization of the regions where they settle and, at the same time, a major participation in and penetration into the urban national hierarchy by new cities.

Therefore, we are present at a new urban order, in search of a decentralization and more equitable joint of the territory, where intermediate cities are allowed to resurge in the urban hierarchy thanks to the development and dynamization of the regions recipient of these airport infrastructures. This has materialized in the notable effects that airports have had in different economic sectors (tourism, housing sector, business ...), as we will see later.

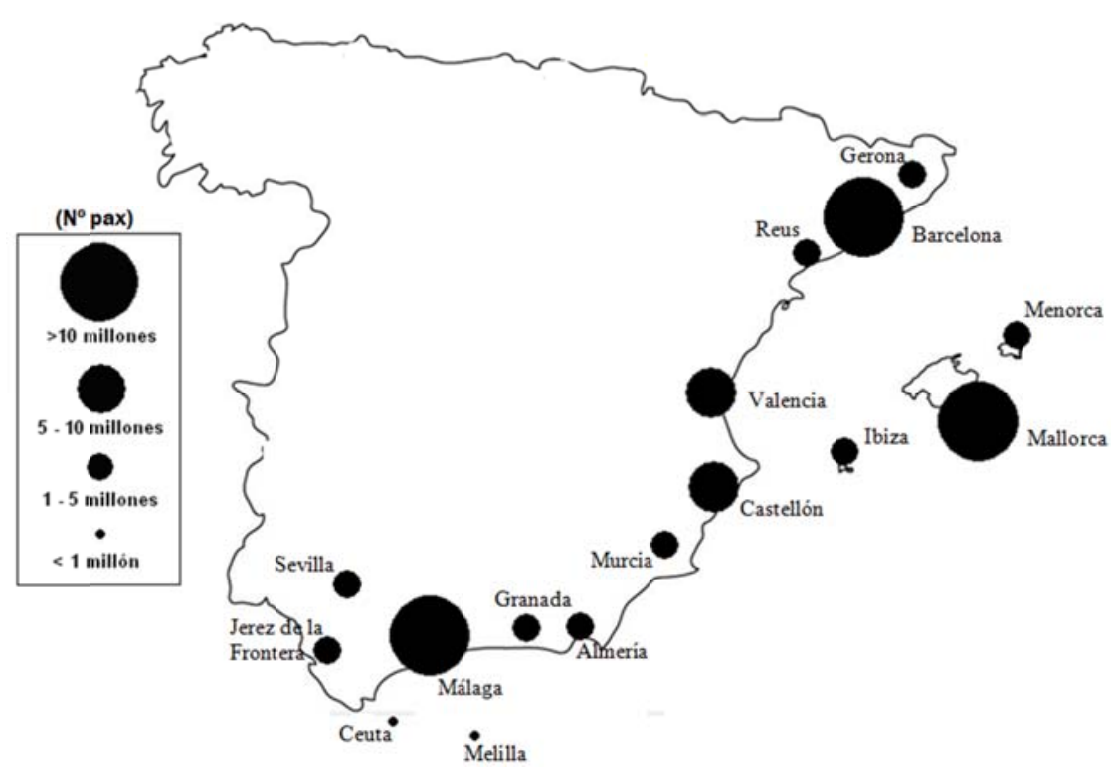

Figure 3. Airport hierarchy (Mediterranean Arch) according to number of passengers (2010) Source: Own elaboration as from dates AENA (Airports and Air Navigation of Spain) 


\section{Macrothink}

Therefore, the low cost phenomenon is helping to change the urban Spanish map in a significant way, since we are turning into from a dual structure (Madrid and Barcelona) - or as much a pentagonal structure (with Seville, Valencia and Bilbao) - to a mesh structure, due to the fact that cheap flights are accentuating the protagonism of Mediterranean average cities that before remained at the margins of the map as Malaga, Alicante, Murcia or Girona, among others.

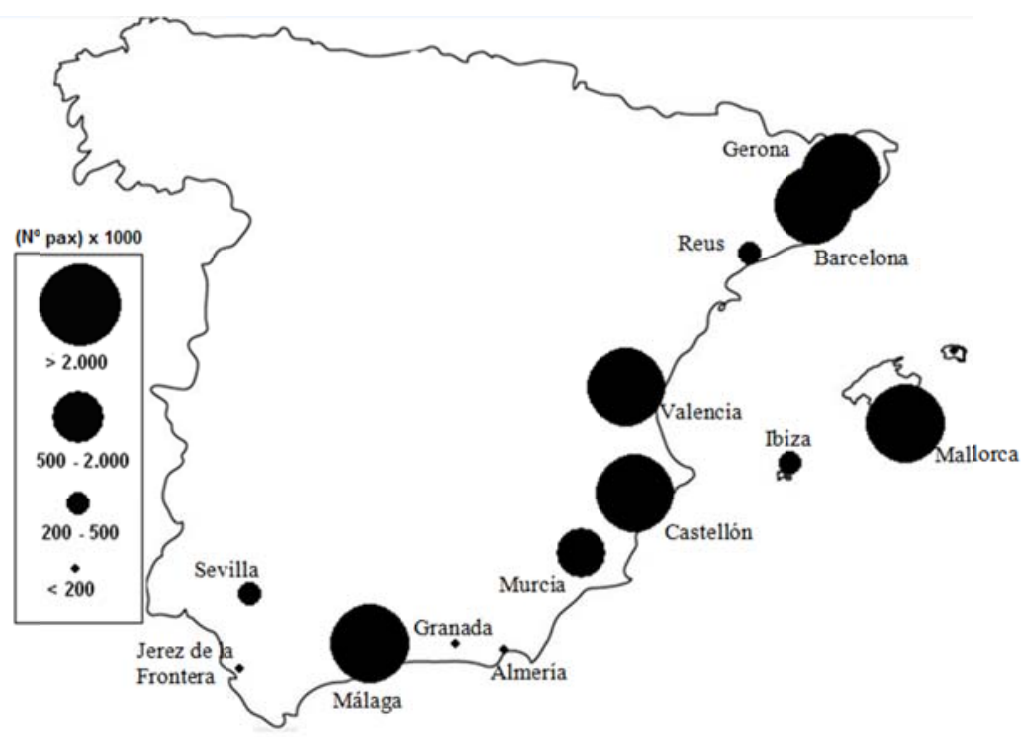

Figure 4. Airport Hierarchy (Mediterranean Arch) linked with the sector low cost (2010) Source: Own elaboration as from information of AENA and Institute of Tourist Studies

In words of the sociologist Cristóbal Torres, we are evolving to a "structure woven of medium cities, linked to forceful regions, with an educated and activate middle class, that is, cities that start experiencing the acceleration of the paces of the social life that was an exclusive characteristic of the metropolis so far”.

If we extend the scale of our observation, we can even analyze these changes at the European level: small cities like Charleroi or Beauvais, average cities such as Edinburgh, Basilea or Pescara, and even big cities like Liverpool are experiencing the opportunity to be inserted in the spaces of top-order relations that globalization demands thanks to air transport and with the entry of a few low cost airlines, which can be competitive there where the biggest ones are not present (Cordoba et al., 2008).

But, in what measures is the modification of the urban Spanish hierarchy materialized? What parameters make it possible to affirm that the intermediate cities are leading a very outstanding socioeconomic and territorial development? Let's analyze some of them: 


\section{Macrothink}

\subsection{Housing Sector}

The expansion of the LCAs is stimulating housing growth in the Spanish Mediterranean region and, consecuently, residential tourism, a specially dynamic sector in the last decade. Specially, the reduction of tariffs and the increase in frequencies and air connections have made possible an accentuation of this sector through the sale of properties as second residences.

By analyzing the growth of the number of secondary residences in the Spanish Autonomous Mediterranean communities that are home to these airport infrastructures, one can observe a constant and well-known increase during the last years, resulting from the strong housing specialization in the coastal spaces of the Mediterranean arch.

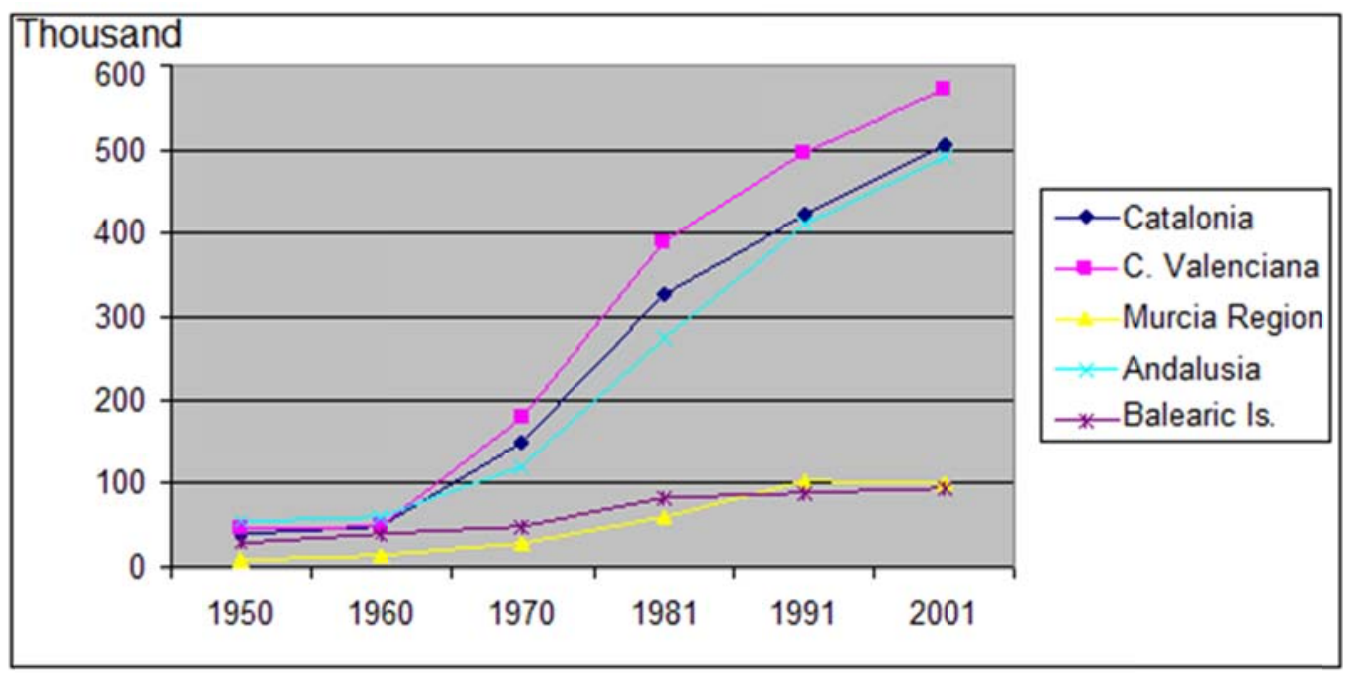

Figure 5. Evolution of the number of secondary residences in Mediterranean Autonomous

Communities of Spain very linked with the phenomenon low cost.

Source: Own elaboration with Spanish Census 1950, 1960, 1970, 1981, 1991 and 2001

The increases in the Valencian Community acquire a specially importance (thanks to the number of tourists who come through the airport of The Altet-Alicante, followed by the airports of Valencia and Castellon), Cataluna (airport of Barcelona, Gerona and Reus) and Andalucia (airports of Malaga, Seville, Jerez and Granada).

In the same way, is it possible to analyze the economic role that these LCA have played by considering the growth of the price of land in different provinces linked with the arrival of these airlines and the renaissance of their corresponding airport equipments. 


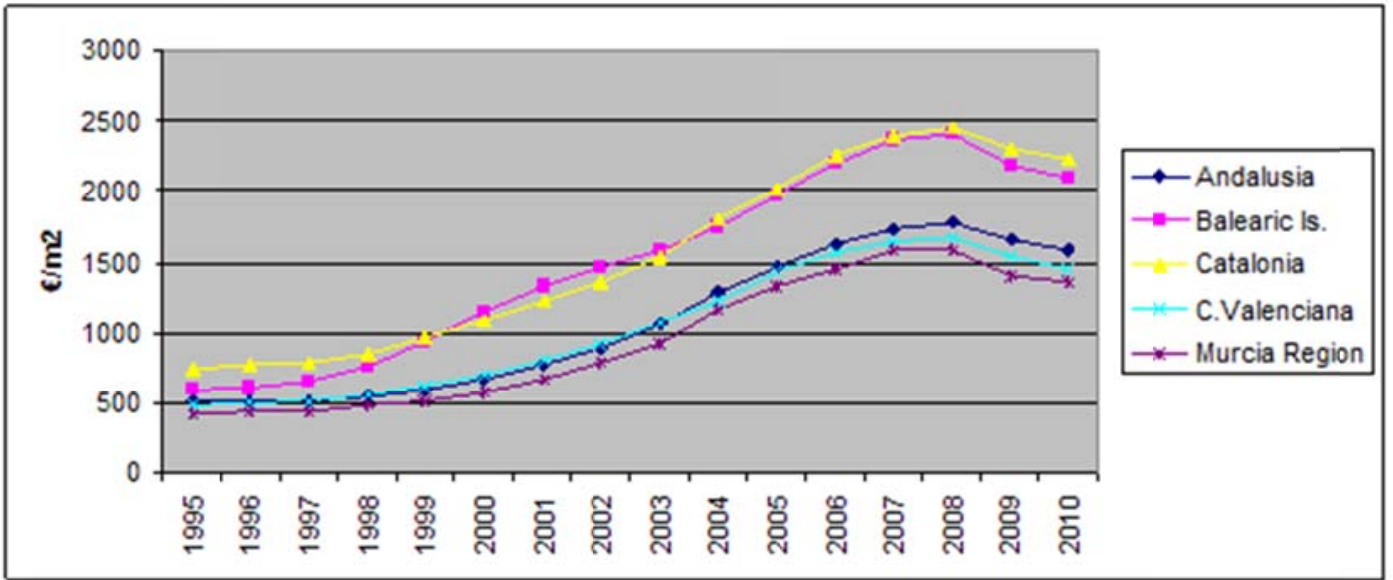

Figure 6. Evolution of the average price of the square meter (average annual) Source: Own elaboration as from dates of Spanish Ministry of Housing

In spite of last year's slight decrease in land prices, the airports of Murcia-San Javier, Santander-Paranas, International Malaga and Gerona-Costa Brava, among others, have taken part in the economic and housing dynamization of their corresponding provinces, contributing to an increase in land prices during the last few years. Moreover, a study realized by the British consulting firm Moneycorp in 2005 stated that the average price of the square meter in many Mediterranean zones near low cost airports grew between 2001 and 2004 at a pace up to three times greater than in equivalent zones in terms of characteristics and tourist attraction, but far away from low cost services.

Hence, the special role that LCA and their associate airports, are playing in this development and dynamization regionally.

\subsection{Tourist Sector}

In advance, we know that a deep relationship exists between tourism and transport in general, because for the development of the former transportation is required from the tourist's habitual place of residence to the tourist destination. Due to this, an increase in tourist activity is translated into a growth and expansion of air traffic, that is, we say that "both elements rely, they are interrelated and they need each other" (Serrano Martínez, 2002).

The increase of the LCA, the reduction of their tariffs, as well as the increase of the routes and of the frequency of the links, facilitate air travel, promoting the development of tourist activity. Different parameters united with this sector testify to it officially in the Mediterranean region.

It is possible to observe the impact of these airlines in regional economies by analyzing the evolution of the contribution of the tourist sector to regional GDP. Many of the average cities that today house a regional low cost airport have seen an increase in the tourist sector's contribution to regional GDP in the last few years. 


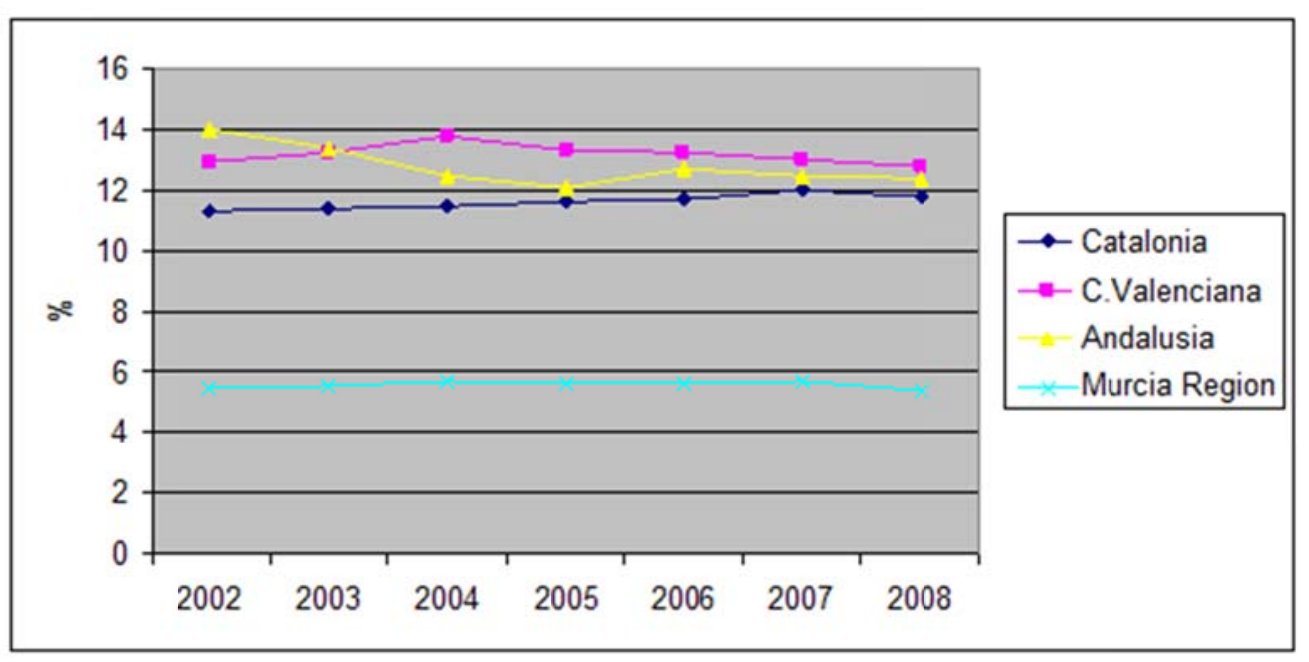

Figure 7. Evolution of the contribution of the tourist sector to regional GDP Source: Exceltur

With regard to the number of tourists who visit Spain, we can observe that coastal cities (with the Sun and Beach tourist model predominant in our country), are the ones that reach major volumes of air traffic in Spain (with the exception of the capital). Concretely, numerous coastal tourist destinations have seen glaring increases in the number of tourists come by air due to the fact that the principal LCA have selected their respective airports as destinations. Such is the case of coastal cities as Malaga (Sun coast), Murcia (Warm coast), Alicante (White coast) or Barcelona (coast of the Maresme), among others.

Nevertheless, the principal cities of the Mediterranean Spanish arch diversify the tourist offer with other modalities in constant growth. For example, urban tourism and weekend getaways in cities such a Barcelona, Valencia or Malaga; the tourism of golf in Murcia; or the idiomatic tourism of Granada and Seville.

Gerona

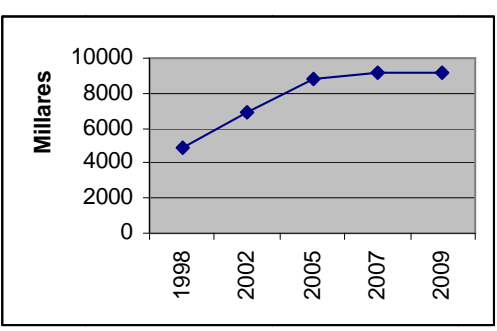

Murcia

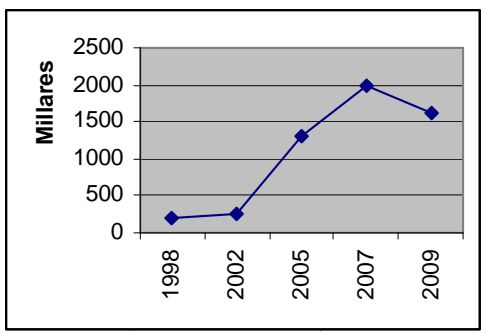

Alicante

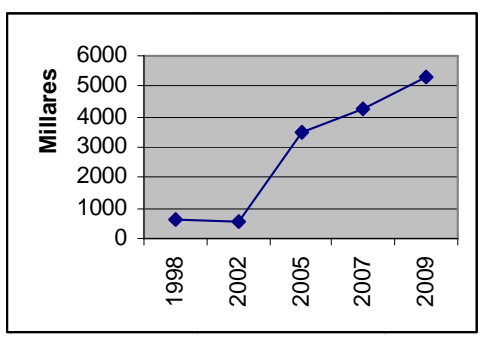

Figure 8. Evolution of the passengers' traffic in different coastal cities with well-known presence of LCA's (1998-2008) Gerona, Murcia, Alicante

Source: Own elaboration as from dates AENA y General Management of Civil Aviation 


\section{Macrothink}

But not only the tourists' arrival demonstrates the importance of these airlines. We also observe a rise in the number of hotel accommodations in Spanish cities of the Mediterranean Arch that have these airport infrastructures linked with the LCA's.

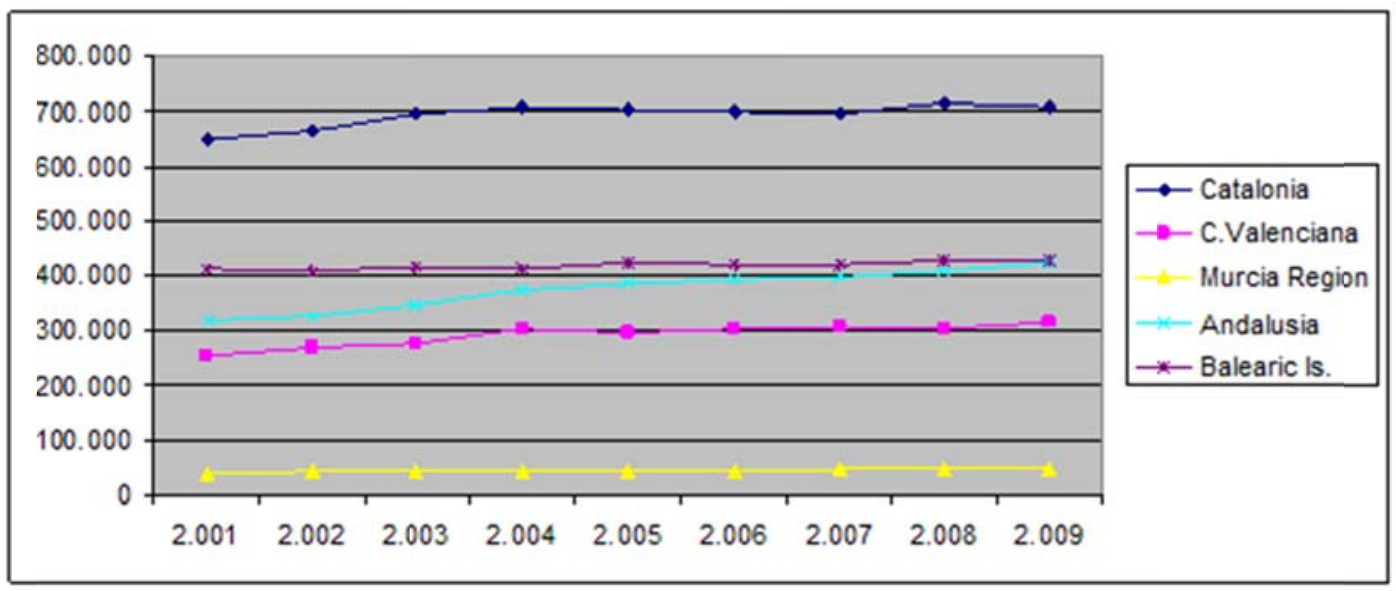

Figure 9. Evolution of the hotel accommodations in tourist housings (August 2001- August 2009)

Source: Own elaboration as from dates AENA y General Management of Civil Aviation

\subsection{Employment Growth}

In the same way, these LCA's have brought about important repercussions in employment, since the installation of one of these companies in a certain regional airport generates direct employment inside the airline itself (pilots, crew, engineers ...), activities united directly with operations of the airport (administration, safety, maintenance, cleanliness ...) and auxiliary activities to the airport (shops, restaurants, other commercial activities ...). It is thought that the LCA directly create approximately 166 jobs for every million passengers (according to ELFFA: The European Low Fares Airlines Association).

Nevertheless, the low cost phenomenon is also capable of indirectly generating employment in the regional economies, especially in sectors related to leisure, tourism and the restaurant industry. This can be observed by analyzing the evolution of the number of members of the Social Security in hotel and catering business and travel agencies. In this case, taking in consideration both previous airports, we see how the trend in both provinces is rising, helping to reduce the rate of unemployment and to lessening the seasonality of travel (it makes possible a major number of trips of weekends and long weekends). 


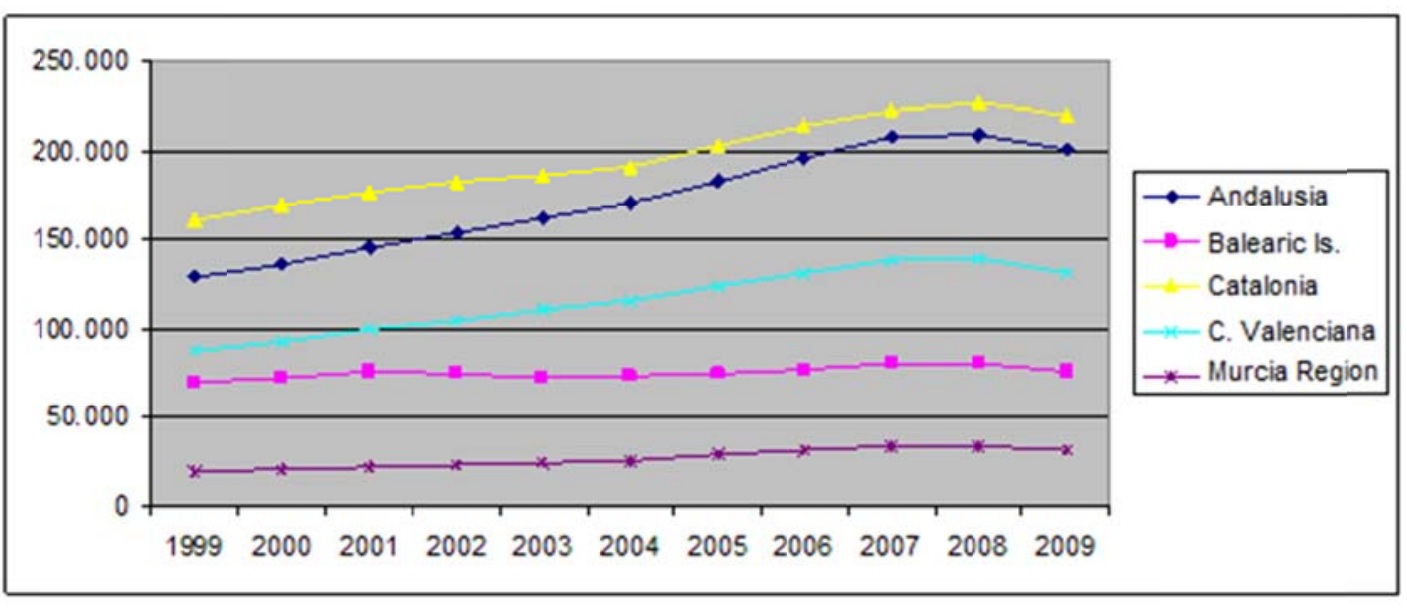

Figure 10. Workers affiliated in labour discharge in Hotel and catering business and Travel agencies in Spanish Mediterranean Arch (1999-2009)

Source: Own elaboration as from dates National Statistic Institute of Spain and Tourist Studies Institute of Spain

At a general level, according to a study of International Airports Council (ACI), it is thought that for every million passengers, about 950 jobs are created approximately in the airport and some 1100 in the surrounding regions. Hence, the appraisals that the Committee of the Regions of the EU considered in 2004:

“... the lower labour costs and facilities costs associated with the more remote regions, can encourage the business community to locate new economic investmest within the region. Existing businesses in the region could develop their market share by being able to reach other parts of the Member State, the EU and the rest of the World".

\subsection{Sector Comercial}

Likewise, the development of these airlines together with the dynamization of these airports has allowed evolving satisfactorily the commercial sector in the areas near these infrastructures. This way, it is possible to corroborate in the Spanish Mediterranean Autonomous Communities, though with a marked current setback as a consequence of the economic world recession. 


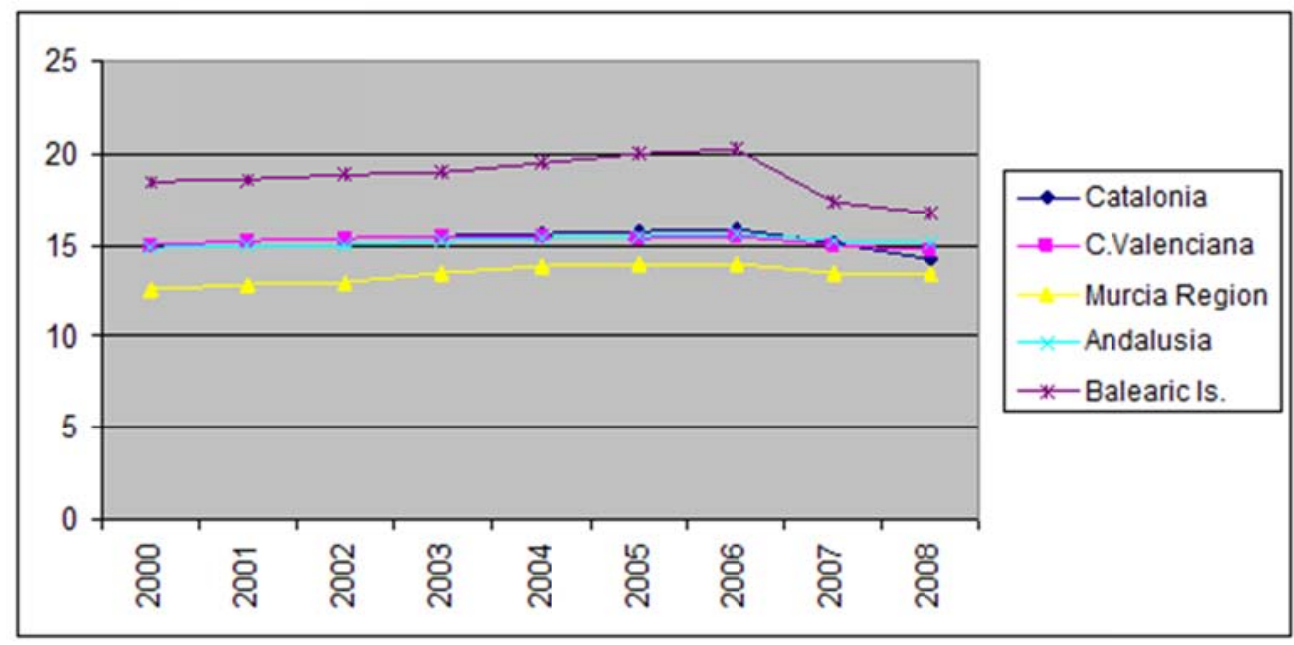

Figure 11. Commercial density (trades per 1000 people) Source: Central Companies Directory of Spaind (DIRCE, in Spanish)

\section{Conclusions}

The condition of proximity to an operative airport today become a decisive factor to help us feel and understand that we live inside of globalization and not on the margins of it, that is, "it contributes to the reduction of isolation in global processes, allowing wide sectors of the population to accede to the top levels of the spatial hierarchy that represents the air transport" (Cordoba \& Gago, 2010).

Nevertheless, in order for an airport to contribute all these benefits it is necessary that the planes take off and land continually. This does not depend ultimately upon the owners and managers of the airport, but rather on the airlines that decide to operate from a certain airport depending on their profit potential.

Hence, this airport dynamization allows us to establish a direct relation between the arrivals of the LCA and the economic development of certain regions. The problem appears with all those spaces far away from these terminals, so, it is increasingly the airline that decides its routes and the airports that it connects to depending on strict cost-benefit calculations, generating with it not only disparities in accessibility of air transport between segments of the population, but also real struggles between competitive airports to attract the liberating function that air transport represents opposite to the afraid local fixation in a society that feels globalized.

That is, Z. Bauman (1994), for reference to R. Robertson (1995), names it as effect glocalizator, since air transport is capable of fixing inexorably to many places that are excessively far away from an airport to be competitive on the world stage.

This idea of proximity-distance to an airport, together with that neoliberal who justifies the search for the maximum benefit on the part of the airlines, helps to deal with and explain why many of these airports resort to economic and financial subsidies to attract low cost carriers: 
in this global and interconnected world, no space wants to feind itself a latecomer isolated from the revitalizing tentacles of contemporary globalization.

Hereby, is observed that the benefits of the LCA and regional airports in Spanish Mediterranean Arch go beyond offering consumers a few more economic tariffs and a major number of connections and frequencies. The benefits carry over to other fields and it is for that reason we can understand the words of the Committee of the Regions of the EU when it affirms:

"The availability of regional air services, and in particular low cost air services, operating from regional airports improves access to the global economy".

Henneber and Tapiador think that "the regional airports are central pillars in territorial planning and one of the most important factors contributing to the endogenous development and socioeconomic dynamism of their regional surroundings " (Henneberg, Tapiador, 2007).

With all this, and given the premature existence of this sector, only time can tell if we are witnessing a fleeting event, ephemeral and transitory or, on the contrary, a sector that, in spite of its marked flexibility, seeks to become strong and consolidated in the Mediterranean Arch in the current tourist panorama of the 21st century.

\section{References}

ABC World International Airways Guides. 1970 and 2009.

Bauman, Z. (1994). Globalization. The Human Consequences. Oxford-Cambridge, BlackwellPolity Press.

Cordoba, J. et al. (2008). Transporte aéreo y espacialidad diferencial. In Homenaje al Profesor José Manual Casas Torres (pp. 45-64). Madrid.

Cordoba, J. Y., \& Gago, C. (2010): Latin American cities and globalización: Change and permanency in the context of development expectations. Urban Studies, 74(9), 2003-2021. http://dx.doi.org/10.1177/0042098010372680

Henneberg, J. M., \& TAPIADOR, F. J. (2007). La eclosión de los aeropuertos regionales españoles. Universidad de Castilla-La Mancha, Lleida y Zaragoza. Fundación Albertis. Barcelona.

Ivars Baidal, J. A. (2006). La expansión de las compañías aéreas de bajo coste: Análisis del impacto en la actividad turística española. Congreso de Turismo, Universidad y Empresas. Mayo 2006.

Pedreño, A. (2007). Innovación en la aviación mundial y globalización. Blog personal de “Economía de la Globalización”. Universidad de Alicante. Alicante.

Robertson, R. (1995). Glocalization: Time-space and Homogeneityheterogeneity. In M.FEATHERSTONE et al. (comps.), Global Modernities (pp.23-44). Londres, Sage. http://dx.doi.org/10.4135/9781446250563.n2 


\section{Macrothink}

International Journal of Social Science Research

ISSN 2327-5510 2015, Vol. 3, No. 1

SERRANO MARTÍNEZ, J. (2002). Grandes centros de transporte aéreo y flujos turísticos en Europa (pp. 137-164). Cuadernos de Turismo. N 9.

Websites

- www.aena.es (Airports and Air Navigation of Spain - AENA)

- $\quad$ www.mfom.es/aviacioncivil/ (General Management of Civil Aviation - DGAC)

- www.fomento.es (Ministerio de Fomento)

- www.aecaweb.com (Spanish Association of Airlines - AECA)

- www.iet.tourspain.es (Institute of Tourist Studies - IET)

- www.ine.es (National Statistic Institute of Spain - INE)

- www.exceltur.org (Alliance for the Tourist Excellence - EXCELTUR)

- www.elfaa.com (European Low Fares Airline Association - ELFAA)

- $\quad$ www.fomento.es (Spanish Ministry of Housing)

- www.ine.com (Central Companies Directory of Spain - DIRCE)

\section{Copyright Disclaimer}

Copyright for this article is retained by the author(s), with first publication rights granted to the journal.

This is an open-access article distributed under the terms and conditions of the Creative Commons Attribution license (http://creativecommons.org/licenses/by/3.0/). 